\title{
Effects of dietary crude protein concentration on late-lactation dairy cow performance and indicators of nitrogen utilization
}

\author{
T. Barros, ${ }^{* 1}$ M. A. Quaassdorff, ${ }^{* 1}$ M. J. Aguerre, ${ }^{*}$ J. J. Olmos Colmenero,† S. J. Bertics, ${ }^{*}$ P. M. Crump, \\ and M. A. Wattiaux ${ }^{* 2}$ \\ *Department of Dairy Science, University of Wisconsin-Madison, Madison 53706 \\ †Departamento de Ciencias Pecuarias y Agricolas, Centro Universitario de Los Altos de la Universidad de Guadalajara, Tepatitlán, Jalisco, \\ México, 47600 \\ ‡Department of Computing and Biometry, University of Wisconsin-Madison, Madison 53706
}

\begin{abstract}
The objectives of this study were to measure performance responses and to evaluate indictors of $\mathrm{N}$ utilization in late-lactation cows fed diets with incremental reductions in crude protein $(\mathrm{CP})$ concentration. Holstein cows ( $\mathrm{n}=128 ; 224 \pm 54 \mathrm{~d}$ in milk) were stratified by parity and days pregnant ( $86 \pm 25 \mathrm{~d}$ ) and randomly assigned to 1 of 16 pens in a randomized complete block design. For $3 \mathrm{wk}$, all cows received a covariate diet containing $16.9 \% \mathrm{CP}$ [dry matter (DM) basis]. For the subsequent $12 \mathrm{wk}$, pens were randomly assigned to 1 of 4 treatments that contained 16.2, 14.4, 13.1, or $11.8 \%$ CP (DM basis). Diets were offered once daily and contained $32.5 \%$ corn silage, $32.5 \%$ alfalfa silage, $13.5 \%$ high-moisture corn, and $21.5 \%$ concentrate mix. A reduction in dietary $\mathrm{CP}$ was achieved by replacing soybean meal with soy hulls in the concentrate mix (DM basis). Dry matter intake, milk urea N (MUN; $\mathrm{mg} / \mathrm{dL}$ ), and the yield of milk urea $\mathrm{N}(\mathrm{g} / \mathrm{d}$ ) decreased linearly with dietary CP. Compared with a $16.2 \% \mathrm{CP}$ diet, a $14.4 \%$ CP diet did not alter milk yield throughout the study, but the 13.1 and $11.8 \% \mathrm{CP}$ diets reduced milk yield after 4 and 1 wk, respectively. Furthermore, milk protein percentage was reduced for all dietary $\mathrm{CP}$ less than $16.2 \%$, but this negative effect was temporary and disappeared after $7 \mathrm{wk}$ for the $14.4 \% \mathrm{CP}$ diet. In contrast, MUN adjusted to a new steady state within $1 \mathrm{wk}$ for all dietary treatments. Modeling quadratic responses with a plateau led to predictions of no reduction in fat- and protein-corrected milk $(32.6 \mathrm{~kg} / \mathrm{d})$ and yields of fat $(1.31 \mathrm{~kg} / \mathrm{d})$, lactose $(1.49 \mathrm{~kg} / \mathrm{d})$, and true protein $(1.12 \mathrm{~kg} / \mathrm{d})$ until dietary $\mathrm{CP}$ decreased below $15.5,15.3,15.9$, and $16.2 \%$, respectively. In this
\end{abstract}

Received August 24, 2016.

Accepted March 14, 2017.

${ }^{1}$ These authors contributed equally to this paper.

${ }^{2}$ Corresponding author: wattiaux@wisc.edu study, MUN and the yield of MUN were highly correlated with $\mathrm{N}$ intake, milk protein yield, and fat- and protein-corrected milk. Surprisingly, N use efficiency (milk protein $\mathrm{N}$ /intake $\mathrm{N}$ ) was not correlated with any variables related to $\mathrm{N}$ utilization and reached an apparent upper limit of approximately 30\%. Although this observation may be associated with feeding diets deficient in metabolizable protein, late-lactation cows in this study adjusted to low dietary CP concentration better than anticipated as milk production was 2.6, 3.6, 6.4 , and $8.0 \mathrm{~kg} / \mathrm{d}$ higher than National Research Council (2001)-predicted metabolizable protein-allowable milk for dietary $\mathrm{CP}$ of $16.2,14.4,13.1$, and $11.8 \%$, respectively.

Key words: late lactation, nitrogen use efficiency, milk performance, milk urea nitrogen

\section{INTRODUCTION}

Pressure on the dairy industry to reduce its environmental impact (Steinfeld et al., 2006) has fueled interest in feeding low-CP diets. Overfeeding dietary CP contributes to low $\mathrm{N}$ use efficiency (NUE, calculated as milk protein N/intake N; Bequette et al., 2003; Huhtanen and Hristov, 2009) and an undesirable effect on water and air quality because of increased urinary urea $\mathrm{N}$ excretion, which is a labile form of $\mathrm{N}$ (Broderick, 2003; Hristov et al., 2004; Burgos et al., 2007). Excess dietary CP may also increase feeding costs and negatively affect farm profit margins (Godden et al., 2001). Furthermore, the high volatility in energy (corn grain) and protein (soybean) prices and the abundance of economical by-products with moderate CP concentrations (e.g., distillers grains) create challenges in formulating balanced rations that simultaneously minimize cost and dietary CP concentration. Results from recent studies have suggested that yields of milk and protein were not increased by feeding more than 16.5\% CP (Broderick, 2003; Ipharraguerre and Clark, 2005; Colmenero and Broderick, 2006). Although some 
of these findings have been obtained with peak- or midlactation cows in Latin square trials with 2 wk of dietary adaptation periods (Broderick, 2003; Colmenero and Broderick, 2006), Law et al. (2009) suggested that when substantial changes in dietary CP were applied, cows' responses to dietary shifts did not always stabilize within 2 wk. Furthermore, these authors reported that reducing dietary $\mathrm{CP}$ at 151 DIM from 17.3 to $14.4 \%$ of DM had no detrimental effect on milk yield (MY) in the later part of the lactation. Therefore, the optimal dietary $\mathrm{CP}$ that sustains $\mathrm{MY}$ in late lactation may be lower than commonly practiced (Kaiser and Shaver, 2006) or recommended by NRC (2001), which predicts a curvilinear decline in MY with declining dietary CP concentration below approximately $16.5 \%$. Thus, in this trial, a randomized complete block design was used to determine responses of late-lactation cows to substantial reductions in dietary $\mathrm{CP}$ concentration over a 12-wk period. Our main hypotheses were that (a) milk performance and N-related responses would be quadratic; (b) significant treatment $\times$ week interactions would be detected, reflecting differential changes in response variables over time depending on the extent of reduction in dietary $\mathrm{CP}$ concentration; and (c) changes in indicators of $\mathrm{N}$ utilization (e.g., MUN) would closely reflect changes in cows' responses to decreasing dietary CP. Thus, our objectives were (a) to determine the pattern of the responses to incremental reductions in dietary $\mathrm{CP}$ concentration in late lactation and, when applicable, search for the minimal dietary CP concentration that maintains maximal performance; (b) to identify and explore response variables for which there was a treatment $\times$ time interaction; and (c) to determine correlations among performance responses and indicators of $\mathrm{N}$ utilization.

\section{MATERIALS AND METHODS}

The Institutional Animal Care and Use Committee of the College of Agricultural and Life Sciences of the University of Wisconsin-Madison approved the experimental protocol for this study, which was conducted from September to December 2013 at the University of Wisconsin-Madison Emmons Blaine experimental station (Arlington, WI).

\section{Cows, Diet, and Experimental Design}

A total of 128 Holstein cows greater than 150 DIM $(224 \pm 54$; mean $\pm \mathrm{SD})$ were stratified by parity $(2.5$ \pm 1.3 lactations $)$ and days pregnant $(86 \pm 25 \mathrm{~d})$ and randomly assigned to 1 of 16 pens (experimental units), each including 2 primiparous and 6 multiparous cows. The study was initiated with a 3 -wk covariate period in which all cows were fed a diet containing $16.9 \% \mathrm{CP}$ (DM basis). For the subsequent 12 wk (experimental period), pens were blocked by 1 of 2 barn wings and randomly assigned to 1 of 4 dietary treatments that contained 16.2, 14.4, 13.1, and 11.8\% CP (DM basis; Table 1). Diets were mixed and fed once daily at $0700 \mathrm{~h}$ as a TMR containing approximately $65 \%$ forage $(32.5 \%$ corn silage and $32.5 \%$ alfalfa silage), $13.5 \%$ high-moisture corn, and $21.5 \%$ concentrate mix (DM basis). The $\mathrm{CP}$ reduction in the diet was achieved by replacing soybean meal with soy hulls in the concentrate mix, which was prepared at the University of Wisconsin Feed Mill (Arlington, WI; Table 2). Diets were offered ad libitum, allowing for 5 to $10 \%$ refusal. The amount of each feed ingredient in the TMR was adjusted weekly for change in percentage of DM in forages.

\section{Feed Sampling and Analysis}

Samples of feed ingredients (corn silage, alfalfa silage, high-moisture corn, and concentrate mixes), TMR, and refusals were obtained weekly, dried at $60^{\circ} \mathrm{C}$ for 48 $\mathrm{h}$ in a forced-air oven, and ground through a 1-mm screen (Wiley mill; Arthur H. Thomas, Philadelphia, $\mathrm{PA}$ ). To monitor $\mathrm{CP}$ (total $\mathrm{N} \times 6.25$ ) concentration of the TMR, ground samples of feed ingredients and TMR were analyzed weekly for total N (method 990.03, AOAC International, 2000; Leco FP-2000 Nitrogen Combustion Analyzer, Leco, St. Joseph, MI). Weekly samples were dried at $105^{\circ} \mathrm{C}$ for $24 \mathrm{~h}$ to determine absolute DM, and dried samples were used to determine ash (method 942.05; AOAC International, 2006). Nutrient composition was determined on wk 2 and 3 composite samples of the covariate period and monthly composite samples during the experimental period. The NDF procedure included $\alpha$-amylase and sodium sulfite (Van Soest et al., 1991). Acid detergent fiber and ADL were determined according to AOAC (1990) method 973.18. Determination of NDIN and ADIN was done by pelleting the F57 Ankom bags (Ankom Technology, Macedon, NY) containing the NDF and ADF residues before $\mathrm{N}$ analysis as described previously. Dairyland Laboratories Inc. (Arcadia, WI) analyzed samples for starch (Bach Knudsen, 1997; YSI Biochemistry Analyzer, YSI Inc., Yellow Springs, OH) and 48-h in vitro NDF digestibility (Holden, 1999; Ankom Daisy Incubator, Ankom Technology). The same laboratory also analyzed a single covariate and a single experimental composite sample for ether extract (method 942.05; AOAC International, 2006). Daily DMI and N intake were determined on a pen basis using absolute DM percentages and weights of as-fed TMR offered and refused, which were obtained from Feed Supervisor Software (Supervisor Systems, Dresser, WI). 
Table 1. Ingredient and chemical composition of covariate diet and dietary treatments

\begin{tabular}{|c|c|c|c|c|c|}
\hline \multirow[b]{2}{*}{ Item } & \multirow[b]{2}{*}{ Covariate } & \multicolumn{4}{|c|}{ Dietary CP, \% of DM } \\
\hline & & 16.2 & 14.4 & 13.1 & 11.8 \\
\hline \multicolumn{6}{|l|}{ Ingredient, $\%$ of DM } \\
\hline Corn silage & 31.3 & 33.5 & 33.8 & 33.8 & 33.7 \\
\hline Alfalfa silage & 33.6 & 31.4 & 31.8 & 31.7 & 31.7 \\
\hline High-moisture corn & 13.1 & 13.6 & 14.0 & 13.8 & 13.9 \\
\hline \multicolumn{6}{|l|}{ Concentrate mix } \\
\hline Soybean meal, $48 \%$ & 12.29 & 12.01 & 7.64 & 3.85 & 0.00 \\
\hline Soy hull pellets & 0.00 & 0.00 & 3.80 & 7.71 & 11.56 \\
\hline Beet pulp & 5.43 & 5.31 & 5.06 & 5.11 & 5.11 \\
\hline Molasses & 2.27 & 2.22 & 2.12 & 2.14 & 2.14 \\
\hline Calcium carbonate & 0.73 & 0.71 & 0.68 & 0.69 & 0.69 \\
\hline TMV premix ${ }^{1}$ & 0.44 & 0.42 & 0.41 & 0.41 & 0.41 \\
\hline Monosodium phosphate & 0.40 & 0.39 & 0.37 & 0.37 & 0.37 \\
\hline Magnesium oxide & 0.32 & 0.32 & 0.30 & 0.30 & 0.30 \\
\hline Sodium chloride & 0.12 & 0.12 & 0.12 & 0.12 & 0.12 \\
\hline \multicolumn{6}{|l|}{ Nutrient $^{2}$} \\
\hline DM, $\%$ as fed & 53.9 & 53.2 & 52.8 & 52.8 & 52.9 \\
\hline $\mathrm{CP}$ & 16.9 & 16.2 & 14.4 & 13.1 & 11.8 \\
\hline Nonforage NDF & 4.5 & 4.3 & 5.9 & 8.4 & 9.9 \\
\hline Forage NDF & 24.7 & 25.4 & 25.6 & 25.6 & 25.6 \\
\hline NDF & 29.2 & 29.6 & 31.5 & 33.9 & 35.5 \\
\hline Ether extract & 3.64 & 3.56 & 3.64 & 3.70 & 3.73 \\
\hline Ash & 7.15 & 7.31 & 7.09 & 6.86 & 6.97 \\
\hline $\mathrm{NFC}^{3}$ & 46.1 & 45.2 & 45.3 & 44.4 & 44.1 \\
\hline Starch & 21.2 & 21.6 & 21.9 & 21.7 & 21.9 \\
\hline NDIN & 0.35 & 0.31 & 0.31 & 0.32 & 0.34 \\
\hline ADIN & 0.17 & 0.14 & 0.14 & 0.14 & 0.13 \\
\hline $\mathrm{ADL}$ & 4.77 & 4.53 & 4.26 & 4.43 & 4.70 \\
\hline $\mathrm{NE}_{\mathrm{L}},{ }^{4} \mathrm{Mcal} / \mathrm{kg}$ of DM & 1.58 & 1.58 & 1.56 & 1.53 & 1.52 \\
\hline
\end{tabular}

${ }^{1}$ Trace mineral and vitamin premix (DM basis): $52.3 \% \mathrm{Cl} ; 34.7 \% \mathrm{Na} ; 0.5 \% \mathrm{Ca} ; 2.11 \% \mathrm{Zn} ; 1.47 \% \mathrm{Mn} ; 0.50 \%$ $\mathrm{Cu} ; 0.09 \% \mathrm{~S} ; 479 \mathrm{mg} / \mathrm{kg}$ of I; $91 \mathrm{mg} / \mathrm{kg}$ of Se; $80 \mathrm{mg} / \mathrm{kg}$ of Co; $2,103,287 \mathrm{IU} / \mathrm{kg}$ of vitamin A; $421,108 \mathrm{IU} / \mathrm{kg}$ of vitamin $\mathrm{D} ; 8,918 \mathrm{IU} / \mathrm{kg}$ of vitamin $\mathrm{E}$.

${ }^{2}$ Nutrients expressed as a percentage of DM unless stated otherwise.

${ }^{3} \mathrm{NFC}=100-[\mathrm{CP} \%+(\mathrm{NDF} \%-$ neutral detergent insoluble $\mathrm{CP} \%)+$ ether extract $\%+$ ash $\%]$.

${ }^{4}$ Estimated using NRC (2001) with DMI, BW, milk yield, and milk composition observed during the trial.

Table 2. Dietary ingredient chemical composition ${ }^{1}$

\begin{tabular}{|c|c|c|c|c|c|c|c|c|}
\hline Nutrient $^{2}$ & $\begin{array}{l}\text { Corn } \\
\text { silage }\end{array}$ & $\begin{array}{l}\text { Alfalfa } \\
\text { silage }\end{array}$ & $\begin{array}{l}\text { High-moisture } \\
\text { corn }\end{array}$ & \multicolumn{5}{|c|}{ Concentrate $\mathrm{mix}^{3}$} \\
\hline DM, $\%$ as fed & $38.6(6.3)$ & $36.3(1.7)$ & $72.9(2.9)$ & $89.0(0.8)$ & $89.7(0.7)$ & $89.8(1.2)$ & $90.1(1.1)$ & $90.3(0.5)$ \\
\hline NDF & $33.1(4.3)$ & $44.7(0.9)$ & $4.9(0.2)$ & 17.7 & $16.8(0.2)$ & $25.4(1.3)$ & $37.0(0.9)$ & $44.6(2.4)$ \\
\hline $\mathrm{NDFD}_{48}, \% \mathrm{NDF}$ & $63.1(0.8)$ & $44.1(1.6)$ & - & - & - & - & - & - \\
\hline IVTDMD $_{48}$ & $86.0(1.5)$ & $73.5(0.8)$ & - & - & - & - & - & - \\
\hline Starch & $34.6(3.2)$ & $1.0(0.14)$ & $70.0(1.3)$ & 1.75 & $1.6(0.15)$ & $1.4(0.02)$ & $1.2(0.05)$ & $1.6(0.17)$ \\
\hline $\mathrm{NFC}^{4}$ & $52.3(3.8)$ & $26.3(1.4)$ & $82.2(0.4)$ & $43.4(3.7)$ & $41.4(0.5)$ & $41.6(2.8)$ & $37.2(0.7)$ & $35.6(3.3)$ \\
\hline NDIN & $0.16(0.02)$ & $0.39(0.01)$ & $0.11(0.04)$ & $0.64(0.01)$ & $0.56(0.01)$ & $0.59(0.06)$ & $0.63(0.05)$ & $0.71(0.05)$ \\
\hline ADIN & $0.05(0.01)$ & $0.23(0.01)$ & $0.00(0.00)$ & $0.32(0.03)$ & $0.23(0.00)$ & $0.26(0.00)$ & $0.26(0.00)$ & $0.22(0.01)$ \\
\hline $\mathrm{ADL}$ & $2.00(0.35)$ & $8.42(0.46)$ & $0.66(0.35)$ & $5.56(1.9)$ & $5.25(0.51)$ & $4.01(0.68)$ & $4.79(0.12)$ & $6.14(0.55)$ \\
\hline
\end{tabular}

${ }^{1}$ Values in parentheses indicate standard deviation; absence of values in parentheses indicates a single data point value.

${ }^{2}$ Percentage of DM unless stated otherwise. $\mathrm{NDFD}_{48}=\mathrm{NDF}$ digestibility (48-h in vitro incubation); IVTDMD $48=$ in vitro DM digestibility (48-h incubation).

${ }^{3}$ Concentrate mix used in the covariate diet and the experimental diets, including 16.2, 14.4, 13.1, and $11.8 \%$ dietary CP.

${ }^{4} \mathrm{NFC}=100-[\mathrm{CP} \%+(\mathrm{NDF} \%-$ neutral detergent insoluble $\mathrm{CP} \%)+$ ether extract $\%+$ ash $\%]$. 


\section{Milking Sampling and Analysis}

Multiparous cows received BST (Posilac, Elanco Animal Health, Greenfield, IN) according to the label every $14 \mathrm{~d}$ starting on $\mathrm{d} 1$ of the covariate period. Cows were milked twice daily, and MY was recorded from individual cows. Cows were dried off and removed from a pen when a 4-d rolling average MY was equal to or less than $11 \mathrm{~kg} / \mathrm{d}$. Milk samples were taken from individual cows during the last 4 consecutive milkings of the covariate period. Individual cow milk samples were obtained weekly from 2 consecutive milkings during the experimental period. Samples were preserved with 2-bromo-2-nitropropan-1,3-diol and sent to AgSource Milk Analysis Laboratory (Menomonie, WI) to be analyzed for true protein, fat, lactose, SNF, and MUN concentrations by infrared analysis and for SCC by flow cytometry using a CombiFoss $6600 \mathrm{FT}+/$ FC (Foss Electric, Hillerød, Denmark). For each cow, yields of milk components were calculated by multiplying component concentration by MY for the a.m. and p.m. samplings. For each pen, daily MY and daily milk component yields were calculated by summing the a.m. and p.m. yields of each cow in the pen. Daily milk component concentrations were calculated by dividing milk component yields by MY. Pen-level MY and milk component yields were divided by the number of cows in a pen before analysis, so the analyzed and reported values reflect average individual animal performance within the pen. Yield of fat- and protein-corrected milk (FPCM) was calculated according to the IDF (2015) equation, and yield of ECM was calculated according to DRMS (2014).

\section{$B W$ and $B C S$}

Body weight and BCS were measured on individual cows after the a.m. milking but were analyzed and reported as average BW and average BCS for a pen (n $=16$ ). Initial $\mathrm{BW}$ was determined the last week of the covariate period. During the experimental period, BW was determined on individual cows in wk 2, 7, 8, 9, 10, 11 , and 12 , and daily change in pen BW was calculated using Excel (Microsoft Corp., Redmond, WA) as the slope of the linear regression of average cow BW in the pen versus days fed the dietary treatment. Three trained individuals recorded BCS (scale of 1 to 5 in 0.25-unit increments; Wildman et al., 1982) in experimental period wk 1 (initial BCS), 5, 9, and 12. Average change in BCS for each pen was calculated as outlined for the change in pen BW except that values were reported over the 12 wk of the experimental period. The 16 numerical slope values for change in BW and change in BCS were used in the statistical analysis.

\section{Calculations and Statistical Analysis}

The 5 cows removed from the study were not replaced. Four cows were removed from the $13.1 \% \mathrm{CP}$ treatment in wk 1 (pen 5), wk 2 (pen 12), wk 9 (pen 14), and wk 12 (pen 5) due to mastitis, pneumonia, dry-off, and dry-off, respectively. One cow was removed from the $11.8 \% \mathrm{CP}$ treatment in wk 8 (pen 15) because of lameness. Removal of these cows did not alter the pattern of variation among pens, and no statistical adjustment was deemed necessary. Data were analyzed with the MIXED procedure (SAS Institute, 2012) as a completely randomized block design. Pen was the experimental unit, and week was considered a repeated measure. Various covariance structures were compared to account for autocorrelated errors due to repeated (weekly) measure on the experimental unit, and the first-order autoregressive covariance structure was selected based on Akaike information criterion. Data for which measurements were repeated weekly were analyzed using the following model:

$$
\begin{aligned}
Y_{i j k l}=\mu & +\mathrm{Cov}+T_{i}+B_{k}+P_{l}\left(B_{k} \times T_{i}\right) \\
& +W_{j}+\left(W_{j} \times T_{i}\right)+e_{i j k l},
\end{aligned}
$$

where $Y_{i j k l}$ is the response variable, $\mu$ is the overall mean, Cov is the fixed effect of the covariate measurement, $T_{i}$ is the fixed effect of treatment $(i=1-4), B_{k}$ is the random effect of barn wing $(k=1-2), P_{l}\left(B_{k}\right.$ $\left.\times T_{i}\right)$ is the random effect of pen $(l=1-16)$ nested within barn wing and treatment combination, $W_{j}$ is the fixed effect of week $(j=1-12),\left(W_{j} \times T_{i}\right)$ is the week $\times$ treatment interaction, and $e_{i j k l}$ is the random residual error. Degrees of freedom were calculated using the Kenward-Roger option (Schaalje et al., 2001). Orthogonal polynomial contrasts were used to determine linear and quadratic effects of dietary $\mathrm{CP}$ concentration on response variables. In the presence of a significant treatment $\times$ week interaction effect, the means were graphed and the source of the interaction was explored using the SLICE option of SAS (SAS Institute, 2012). For data without repeated measurements (initial BW, BW change, initial BCS, and BCS change), Cov, $W_{j}$, and $\left(W_{j} \times T_{i}\right)$ were removed from the model described previously. The CORR procedure of SAS (SAS Institute, 2012) was used to correlate $\mathrm{N}$ performance and efficiency variables. Statistical significance and trends were considered at $P \leq 0.05$ and $0.05<P \leq 0.10$, respectively.

To further study the curvilinear responses, least squares means of the variables that showed quadratic effects (at $P \leq 0.1$ ) were regressed on dietary $\mathrm{CP}$ concentration using the RSREG procedure of SAS (SAS 
Institute, 2012) to predict the dietary CP concentration that maximized (or minimized) MY responses and efficiency measures. All predicted maxima (and minima) were within but near the upper experimental dietary CP concentration (i.e., 16.2\%). Thus, an alternative model describing a saturation behavior was used to determine the dietary $\mathrm{CP}$ concentration at which a response variable began to deviate from its plateau (i.e., maxima or minima). The NLIN procedure of SAS (SAS Institute, 2012) was used with the following model (referred to herein as the quadratic model with a plateau):

$$
\begin{gathered}
\text { if } X \leq X_{o} \text {, then } Y=Y_{\max }-b\left(X_{o}-X\right)^{2}, \\
\text { else } Y=Y_{\max },
\end{gathered}
$$

where $X$ is dietary CP concentration, $X_{o}$ is the dietary $\mathrm{CP}$ concentration at which the response reaches the plateau as dietary $\mathrm{CP}$ increases, $Y$ is the response variable, $Y_{\max }$ is the plateau, and $b$ is a parameter that describes the curvature of the saturation curve. Conversely, $X_{o}$ can be interpreted as the dietary $\mathrm{CP}$ concentration at which the response variable starts to decline from $Y_{\max }$ as dietary $\mathrm{CP}$ concentration is reduced. For variables that increased with decreasing dietary CP concentration, the model was

if $X \geq X_{o}$, then $Y=Y_{\min }+b\left(X_{o}-X\right)^{2}$, else $Y=Y_{\min }$.

\section{RESULTS AND DISCUSSION}

\section{Dietary Composition}

Composition of TMR and feed ingredients is shown in Tables 1 and 2, respectively. Minimal variation in CP content of all dietary ingredients made it possible to maintain relatively constant $\mathrm{CP}$ concentrations throughout the study. Concentrations of $\mathrm{CP}$ in TMR averaged 16.2, 14.4, 13.1, and $11.8 \% \mathrm{CP}$, and thus the initially intended difference of 1.5 units among treatments was achieved, on average. Because dietary treatments were constructed by substituting a soy product high in nonforage NDF (soy hulls) for a soy product high in CP (soybean meal), the reduction in dietary $\mathrm{CP}$ across treatments was accompanied by an increase in nonforage NDF and a decrease in NRC (2001)-predicted $\mathrm{NE}_{\mathrm{L}}$ (Table 1). Other strategies to reduce dietary CP (replacing the major source of dietary $\mathrm{CP}$ with an energy source) could have maintained $\mathrm{NE}_{\mathrm{L}}$ but would have created other confounding effects. Diets had similar contents of DM $(52.9 \pm 0.2 \%$ as fed $)$ and of forage NDF $(25.6 \pm 0.1 \%)$, NFC $(42.8 \pm 0.7 \%)$, starch $(21.8 \pm 0.2 \%)$, ADL $(4.48 \pm 0.2 \%)$, ether extract $(3.66$ $\pm 0.1 \%)$, NDIN (0.32 $\pm 0.01 \%), \operatorname{ADIN}(0.14 \pm 0.01 \%)$, and ash $(7.06 \pm 0.2 \%)$ on a DM basis. In addition, assuming a DMI of $24.2 \mathrm{~kg} / \mathrm{d}$, the NRC (2001)-predicted $\mathrm{NE}_{\mathrm{L}}$-allowable milk was $33.9,33.2,32.5$, and $31.8 \mathrm{~kg} / \mathrm{d}$, but the MP-allowable milk was 30.1, 27.0, 22.6, and $17.4 \mathrm{~kg} / \mathrm{d}$ for the diets with $16.2,14.4,13.1$, and $11.8 \%$ of $\mathrm{CP}$, respectively, suggesting that all diets were protein limited and that the expected effect of the slight differential energy content among diets was minimal compared with the expected effect due to the reduction in dietary $\mathrm{CP}$ concentration.

\section{Animal Performance}

In this study, the statistical power was not impeded by the limited number of experimental units per treatment ( $\mathrm{n}=4 \mathrm{pens} /$ treatment). The standard errors of the mean of most performance variables presented in Table 3 were less than those reported for a study designed with 40 cows as an incomplete $5 \times 5$ Latin square $(\mathrm{n}=$ 8 cows/treatment; Colmenero and Broderick, 2006). As indicated by St Pierre (2007), the number of replicates required to achieve a given power with pen studies can be substantially less than the number of replicates required when cows are the experimental units provided that the variation between pens is small compared with the variation between cows. As reported in Table 3, DMI decreased linearly with decreasing dietary CP concentration. A similar observation was reported in Broderick (2003), where DMI was greatest $(22.6 \mathrm{~kg} / \mathrm{d})$ at $18.4 \% \mathrm{CP}$ and declined to 22.1 and $21.2 \mathrm{~kg} / \mathrm{d}$ at 16.7 and $15.1 \% \mathrm{CP}$, respectively, in a mid-lactation cow study. Although depressed DMI in cows on low-CP diets could be caused by impaired rumen function via suppressed microbial activity or physiological regulation of intake (Allen, 2000), Colmenero and Broderick (2006) did not find an effect of diets ranging from 19.4 to $13.5 \% \mathrm{CP}$ on DMI of early- and mid-lactation cows. In addition, no change in DMI occurred when soy hulls increased from 4 to 13 and 18\% of dietary DM (Fredin et al., 2015) or from 2 to $17 \%$ of dietary DM (Ferraretto et al., 2012), suggesting that the decrease in DMI observed here was not likely associated with the increase in soy hulls in the diet as dietary $\mathrm{CP}$ was reduced.

Milk yield, FPCM, and ECM declined linearly with decreasing dietary CP. These results agreed with those of Cabrita et al. (2011), who reported depressed milk and corrected MY when cows (134 \pm 45.2 DIM) were fed a $14.3 \% \mathrm{CP}$ diet compared with a $15.7 \% \mathrm{CP}$ diet despite balanced absorbable AA in a 12-wk changeover design experiment. However, in our study there was also a quadratic response indicating that the magnitude of decrease in these variables increased with each incremental decrease in dietary CP (i.e., the smallest de- 
crease was observed when $\mathrm{CP}$ concentration decreased from 16.2 to $14.4 \%$, and the largest decrease was observed when CP concentration decreased from 13.1 to $11.8 \%$ ). Furthermore, in the case of MY, there was a treatment $\times$ week interaction. This interaction was not associated with the reduction in dietary $\mathrm{CP}$ concentration from 16.2 to $14.4 \%$ of dietary DM because MY did not differ between these 2 treatments at any time during the experimental period (Figure 1a). However, reducing dietary CP from 16.2 to $13.1 \%$ of DM reduced MY after 4 wk, and reducing dietary CP from 16.2 to $11.8 \%$ of DM reduced MY within 1 wk of feeding the dietary treatment. Reynolds and Kristensen (2008) discussed the existence of a labile $\mathrm{N}$ pool that cows may rely upon temporarily to maintain a steady state when dietary CP becomes deficient. The absence of a reduction in MY and milk protein production when dietary $\mathrm{CP}$ concentration oscillated substantially over a period of $2 \mathrm{~d}$ suggested the existence of such labile reserves (St-Pierre and Gerstner, 2005). Data from our study suggested that when dietary CP was reduced from 16.2 to $14.4 \%$, these reserves either were not necessary or were sufficient to maintain a steady state for MY.

In contrast to MY, the absence of a treatment $\times$ week interaction for FPCM and ECM suggested milk component compensatory effects. As reported in Table
3 , dietary treatments had a linear depressing effect on milk true protein percentage, but this effect interacted with time. The significant treatment $\times$ week interaction is presented in Figure 1b. Before describing these effects it should be noted, however, that the average milk true protein percentage in this study $(3.47 \%)$ was greater than the $2.80,3.13$, and $3.35 \%$ values reported in Broderick (2003), Colmenero and Broderick (2006), and Law et al. (2009), respectively. As expected for latelactation cows, milk true protein percentage increased over time. However, compared with the $16.2 \% \mathrm{CP}$ diet, milk true protein percentage was reduced when cows were fed reduced dietary $\mathrm{CP}$ within 1 wk; however, the difference between the 16.2 and $14.4 \% \mathrm{CP}$ diets was no longer significant after 7 wk (Figure 1b). These observations suggested a differential rate of change in milk true protein and may have implications for the choice of experimental design and protocol of future trials studying the effects of low dietary CP. Long adaptation periods may be required to capture long-term effects. As illustrated in Figure 1b, the conclusion regarding the effect of reducing dietary $\mathrm{CP}$ concentration on milk true protein percentage would have been different if data collection had been completed in wk 4 (as in a typical Latin square) compared with wk 8 or later. In contrast to the dynamic temporal effect of reducing $\mathrm{CP}$

Table 3. Effect of dietary CP content on cow performance

\begin{tabular}{|c|c|c|c|c|c|c|c|c|}
\hline Item & \multicolumn{4}{|c|}{ Dietary CP, \% of DM } & SEM & \multicolumn{3}{|c|}{$P$-value ${ }^{1}$} \\
\hline DMI, kg/d & 24.2 & 23.8 & 23.8 & 22.7 & 0.27 & $<0.01$ & 0.16 & 0.58 \\
\hline $\mathrm{FPCM},{ }^{2} \mathrm{~kg} / \mathrm{d}$ & 32.6 & 31.9 & 30.0 & 26.1 & 0.84 & $<0.01$ & 0.04 & 0.14 \\
\hline $\mathrm{ECM},{ }^{3} \mathrm{~kg} / \mathrm{d}$ & 35.7 & 35.0 & 32.8 & 28.6 & 0.91 & $<0.01$ & 0.03 & 0.14 \\
\hline \multicolumn{9}{|l|}{ Milk composition } \\
\hline Lactose, \% & 4.69 & 4.70 & 4.66 & 4.69 & 0.03 & 0.71 & 0.77 & 0.61 \\
\hline $\mathrm{SNF}, \%$ & 9.23 & 9.08 & 9.14 & 8.97 & 0.04 & 0.02 & 0.69 & 0.01 \\
\hline \multicolumn{9}{|l|}{ Milk component yields } \\
\hline True protein, kg/d & 1.12 & 1.06 & 0.98 & 0.82 & 0.02 & $<0.01$ & 0.02 & 0.14 \\
\hline Fat, $\mathrm{kg} / \mathrm{d}$ & 1.31 & 1.28 & 1.23 & 1.09 & 0.04 & $<0.01$ & 0.08 & 0.23 \\
\hline Lactose, kg/d & 1.49 & 1.46 & 1.33 & 1.17 & 0.04 & $<0.01$ & 0.02 & 0.06 \\
\hline $\mathrm{SNF}, \mathrm{kg} / \mathrm{d}$ & 2.91 & 2.82 & 2.58 & 2.23 & 0.07 & $<0.01$ & 0.02 & 0.11 \\
\hline BW change, kg/d & 0.29 & 0.45 & 0.34 & 0.15 & 0.08 & 0.20 & 0.04 & NA \\
\hline BCS (initial) & 3.24 & 3.28 & 3.19 & 3.13 & 0.05 & 0.08 & 0.24 & NA \\
\hline BCS change, per 12 wk & 0.11 & 0.07 & 0.25 & 0.11 & 0.12 & 0.54 & 0.66 & NA \\
\hline
\end{tabular}

${ }^{1}$ Probability of a linear $(\mathrm{L})$, quadratic $(\mathrm{Q})$, or treatment $\times$ week $($ Trt $\times$ wk) effect of dietary CP. Week effect was significant $(P \leq 0.01)$ for all response variables. $\mathrm{NA}=$ not applicable.

${ }^{2}$ Fat- and protein-corrected milk $(\mathrm{FPCM})=\operatorname{milk}(\mathrm{kg} / \mathrm{d}) \times(0.1226 \times$ fat $\%+0.0776 \times$ protein $\%+0.2534)($ IDF, 2015)

${ }^{3} \mathrm{ECM}=(12.95 \times$ fat yield $)+(7.65 \times$ true protein yield $)+(0.327 \times$ milk yield $)($ DRMS, 2014 $)$. 
from 16.2 to $14.4 \%$ of the dietary DM (1.6-unit reduction in dietary $\mathrm{CP}$ ), the reduction in dietary $\mathrm{CP}$ by 3.1 units (from 16.2 to $13.1 \%$ of $\mathrm{DM}$ ) and by 4.4 units (from 16.2 to $11.8 \%$ of $\mathrm{DM}$ ) reduced milk true protein percentage by 0.06 and 0.25 units, respectively (Table 3). These responses exhibited themselves within $1 \mathrm{wk}$ of dietary change, with no further readjustments over time (Figure 1b).

Milk true protein yield (MPY) declined in a linear and quadratic fashion with decreasing dietary $\mathrm{CP}$ (Table 3). The MPY was highest $(1.12 \mathrm{~kg} / \mathrm{d})$ in the $16.2 \%$ $\mathrm{CP}$ diet and declined by $0.06,0.11$, and $0.27 \mathrm{~kg} / \mathrm{d}$ when dietary $\mathrm{CP}$ concentration was $14.4,13.1$, and $11.8 \%$, respectively. Cabrita et al. (2011) also reported depressed MPY with decreasing dietary CP (from 15.7 to $14.3 \%$ of DM) regardless of balanced absorbable EAA. Interestingly, no treatment $\times$ week interaction was found for MPY $(P=0.14$; Table 3$)$, although this interaction was significant for both variables used to calculate it (i.e., MY and milk true protein percentage). As illustrated in the graphical data (Figures 1a and 1b), both the extent of reduction of dietary $\mathrm{CP}$ concentration and week on

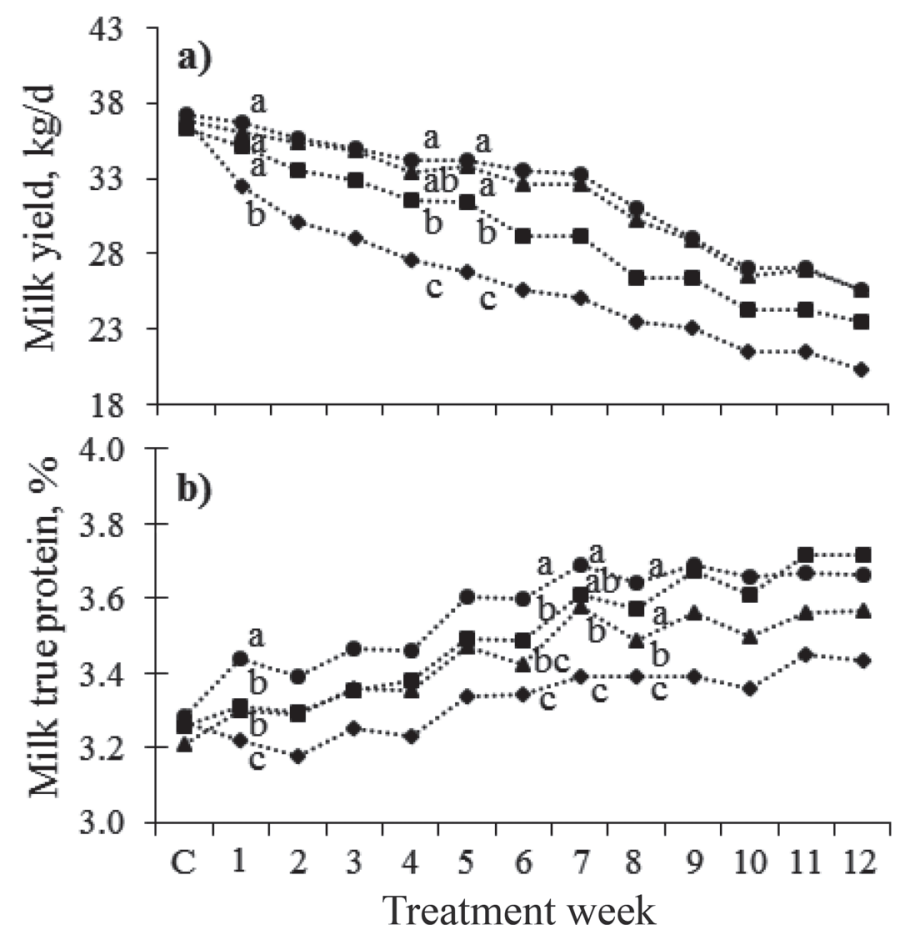

Figure 1. Covariate and covariate-adjusted least squares means for (a) weekly milk yield $(\mathrm{SEM}=0.75 \mathrm{~kg}$ ) and (b) milk true protein percentage $(\mathrm{SEM}=0.03 \%$ ) of cows in late lactation fed diets of decreasing $\mathrm{CP}$ concentration (DM basis). On the $\mathrm{x}$-axis, $\mathrm{C}$ depicts the covariate week. Treatment diets were $16.2 \%(\bullet), 14.4 \%(\mathbf{\Delta}), 13.1 \%$ $(\mathbf{\square})$, and $11.8 \%(\bullet) \mathrm{CP}$ (treatment $\times$ week, $P<0.01$ ). Means within same week with different letters were different at $P \leq 0.05$. When no letters are shown, the pattern carries from the previous week. treatment influenced MY and milk true protein percentage. Thus, the constant difference in MPY among treatments over the duration of the study may be the result of different underlying mechanisms depending on the severity of the reduction in dietary $\mathrm{CP}$.

Treatments did not affect milk fat percentage (Table 3). Therefore, milk fat yield reflected MY and decreased in a linear fashion (with a tendency for quadratic response; $P=0.08$ ) with a reduction in dietary CP. On average, fat percentage was greater $(4.28 \%)$ in this study than in other dietary CP feeding studies, which reported average values of $3.32,3.59$, and $3.96 \%$ for cows with average DIM of 120 in Colmenero and Broderick (2006), 126 in Broderick (2003), and 228 in Law et al. (2009), respectively. Thus, high milk fat (and true protein) percentages observed in this trial may be attributed to the advanced DIM of our late-lactation cows. Milk lactose percentage averaged $4.69 \%$ and was not influenced by dietary treatments (Table 3). In contrast, milk lactose yield declined in a linear and quadratic fashion with decreasing dietary CP. Furthermore, there was a tendency $(P=0.06)$ for a treatment $\times$ week interaction (data not shown) that revealed patterns of changes due to dietary treatments over time that were similar to those described for MY in Figure 1a. This similarity is not surprising because lactose is the major osmotic regulator of milk volume. The SNF percentage averaged $9.11 \%$ and was greater than the averages of $8.96 \%$ reported in both Broderick (2003) and Colmenero and Broderick (2006). In this study, SNF percentage declined linearly with declining dietary CP. For the most part, the changes in SNF percentage and yield reflected the changes described for milk true protein percentage and yield, respectively. The treatment $\times$ week interaction $(P \leq 0.01$; data not shown) for SNF percentage followed the same general trend described for the treatment $\times$ week interaction effect on milk true protein percentage (Figure 1b). Furthermore, there was also a quadratic response for SNF yield $(P=0.02)$, which reflected the combined effects on lactose and MPY (Table 3).

Measures of feed efficiencies (MY/DMI, FPCM/ DMI, and ECM/DMI) declined in a linear and quadratic fashion with decreasing dietary $\mathrm{CP}$, but numerical values were essentially the same for the 16.2 and $14.4 \%$ dietary CP levels (Table 3 ). In contrast, reducing dietary CP concentration from 16.2 to 13.1 and $11.8 \%$ substantially depressed feed efficiency. There was a tendency $(P=0.09)$ for a treatment $\times$ week interaction for MY/DMI, with a pattern of change (data not shown) that mirrored the one described for MY in Figure 1a.

Body weight change exhibited a quadratic $(P=0.04)$ response to dietary $\mathrm{CP}$ treatment. The highest and 
Table 4. Effect of dietary CP concentration on $\mathrm{N}$ intake, $\mathrm{N}$ use efficiency, and indicators of $\mathrm{N}$ utilization

\begin{tabular}{|c|c|c|c|c|c|c|c|c|}
\hline Item & \multicolumn{4}{|c|}{ Dietary CP, \% of DM } & SEM & \multicolumn{3}{|c|}{$P$-value ${ }^{1}$} \\
\hline $\mathrm{N}$ intake, $\mathrm{g} / \mathrm{d}$ & 624 & 547 & 497 & 429 & 5.88 & $<0.01$ & 0.32 & $<0.01$ \\
\hline MUN, mg/dL & 13.3 & 10.1 & 8.05 & 5.97 & 0.30 & $<0.01$ & 0.29 & $<0.01$ \\
\hline MUNY, ${ }^{3} \mathrm{~g} / \mathrm{d}$ & 4.25 & 3.24 & 2.28 & 1.45 & 0.09 & $<0.01$ & 0.31 & $<0.01$ \\
\hline MUNY/MPY, ${ }^{4} \mathrm{~g} / \mathrm{kg}$ & 3.74 & 3.15 & 2.32 & 1.79 & 0.08 & $<0.01$ & 0.06 & $<0.01$ \\
\hline
\end{tabular}

${ }^{1}$ Probability of a linear $(\mathrm{L})$, quadratic $(\mathrm{Q})$, and treatment $\times$ week $($ Trt $\times$ wk) effect of dietary CP. Week was significant $(P \leq 0.01)$ for all response variables.

${ }^{2} \mathrm{~N}$ use efficiency $=100 \times$ milk protein $\mathrm{N}(\mathrm{g} / \mathrm{d}) / \mathrm{N}$ intake $(\mathrm{g} / \mathrm{d})$.

${ }^{3} \mathrm{MUNY}=$ daily excretion of MUN (g/d).

${ }^{4} \mathrm{MUNY} / \mathrm{MPY}=\mathrm{MUN}$ excretion $(\mathrm{g} / \mathrm{d}) /$ milk protein yield $(\mathrm{kg} / \mathrm{d})$.

${ }^{5} \mathrm{MPY} / \mathrm{MUNY}=$ milk protein yield $(\mathrm{g} / \mathrm{d}) / \mathrm{MUN}$ excretion $(\mathrm{g} / \mathrm{d})$.

${ }^{6} \mathrm{MkN} / \mathrm{MkE}=$ milk N $(\mathrm{g} / \mathrm{d}) /$ milk energy $(\mathrm{Mcal} / \mathrm{d})$, where $\mathrm{MkE}=0.00929 \times \mathrm{g}$ of fat $/ \mathrm{d}+0.00563 \times \mathrm{g}$ of true protein $/ \mathrm{d}+0.00395 \times \mathrm{g}$ of lactose/d (NRC, 2001).

${ }^{7} \mathrm{MkN} / \mathrm{aMkE}=\operatorname{milk} \mathrm{N}(\mathrm{g} / \mathrm{d}) /$ available energy for milk $(\mathrm{Mcal} / \mathrm{d})$, where aMkE $=\mathrm{NE}_{\mathrm{L}}$ intake $(\mathrm{Mcal} / \mathrm{d})-\mathrm{NE}_{\mathrm{M}}(\mathrm{Mcal} / \mathrm{d})-\mathrm{NE}$ required for BW change (Mcal/d) (NRC, 2001).

lowest BW gains were observed for the 14.4 and $11.8 \%$ CP diets, respectively (Table 3 ). In this study, average BW gain was $0.31 \mathrm{~kg} / \mathrm{d}$, which was lower than the 0.52 and $0.57 \mathrm{~kg} / \mathrm{d}$ values reported in Broderick (2003) and Colmenero and Broderick (2006), respectively. Furthermore, these same authors reported no effects of feeding diets with a wide range of concentrations of dietary $\mathrm{CP}$ on BW change.

\section{Indicators of N Utilization}

Nitrogen intake ranged from 623 to $429 \mathrm{~g} / \mathrm{d}$ and decreased linearly with a reduction in dietary CP (Table 4). Except for wk 7 (Figure 2a), $N$ intake ranked in the same order as dietary $\mathrm{CP}$ concentration every week of the trial and was consistently the greatest $(P<0.05)$ for the $16.2 \% \mathrm{CP}$ treatment and the least $(P<0.05)$ for the $11.8 \% \mathrm{CP}$ treatment. In the present study, MUN was reduced linearly from 13.3 to $6.0 \mathrm{mg} / \mathrm{dL}$ as dietary $\mathrm{CP}$ was reduced from 16.2 to $11.8 \%$. Changes in MUN reflected the changes in dietary $\mathrm{CP}$ and $\mathrm{N}$ intake (Table 5 ; Figure 2b). These changes occurred the first week after cows were subjected to their dietary treatments and remained consistent thereafter until the end of the trial (Figure 2b). Statistically, however, there was no difference in MUN between the 2 intermediate dietary CP treatments in wk 11 (Figure 2b), which was the reason for a significant treatment $\times$ week interaction (Table 4). Thus, except for wk 11, MUN ranked first (highest), second, third, and fourth (lowest) for cows fed the 16.2, 14.4, 13.1, and $11.8 \% \mathrm{CP}$ diets, respectively (Figure $2 \mathrm{~b})$. Overall, MUN decreased by $1.66 \pm 0.036 \mathrm{mg} / \mathrm{dL}$ per unit of reduction in dietary $\mathrm{CP}$ concentration (Table 4). This decrease was intermediate compared with the values of $2.03 \pm 0.036,1.38 \pm 0.122$, and $1.54 \pm 0.18$ $\mathrm{mg} / \mathrm{dL}$ calculated from Broderick (2003), Colmenero and Broderick (2006), and Ipharraguerre and Clark (2005), respectively. Daily yield of MUN (MUNY) ranged from 1.45 to $4.25 \mathrm{~g} / \mathrm{d}$ and followed the same statistical pattern as described for MUN. In addition, our calculation indicated that MUNY relative to the daily secretion of milk protein $(\mathrm{kg} / \mathrm{d} ; \mathrm{MUNY} / \mathrm{MPY})$ decreased linearly from 3.74 to $1.79 \mathrm{~g} / \mathrm{kg}$ when CP concentration was reduced from 16.2 to $11.8 \%$ (Table 4). In a study of factors influencing NUE on Québec dairy farms, Fadul-Pacheco et al. (2017) reported values for this ratio ranging from 3.38 to 4.03 as NUE decreased from 36 to $22 \%$. The reverse ratio MPY (g/d)/MUNY $(\mathrm{g} / \mathrm{d})$ should be interpreted as the grams of protein secreted by the mammary gland per gram of urea $\mathrm{N}$ in the milk. This ratio increased from 279 to $630 \mathrm{~g} / \mathrm{g}$ in a quadratic fashion with the decrease in dietary $\mathrm{CP}$ concentration (Table 4).

The weekly changes in NUE among dietary treatments were inconsistent and somewhat erratic (Figure 2c). For only 3 of the 12 experimental weeks, NUE was lowest when cows were fed the $16.2 \% \mathrm{CP}$ diet compared with the other dietary CP levels. Furthermore, NUE averaged $30 \%$ and did not differ when cows were fed the 14.4, 13.1, and $11.8 \% \mathrm{CP}$ diets for 11 of the 12 experimental weeks. Overall, the trend for a linear increase in NUE with decreasing dietary CP concentration was attributable to the lower NUE observed in cows fed the $16.2 \% \mathrm{CP}$ diet compared with the other 

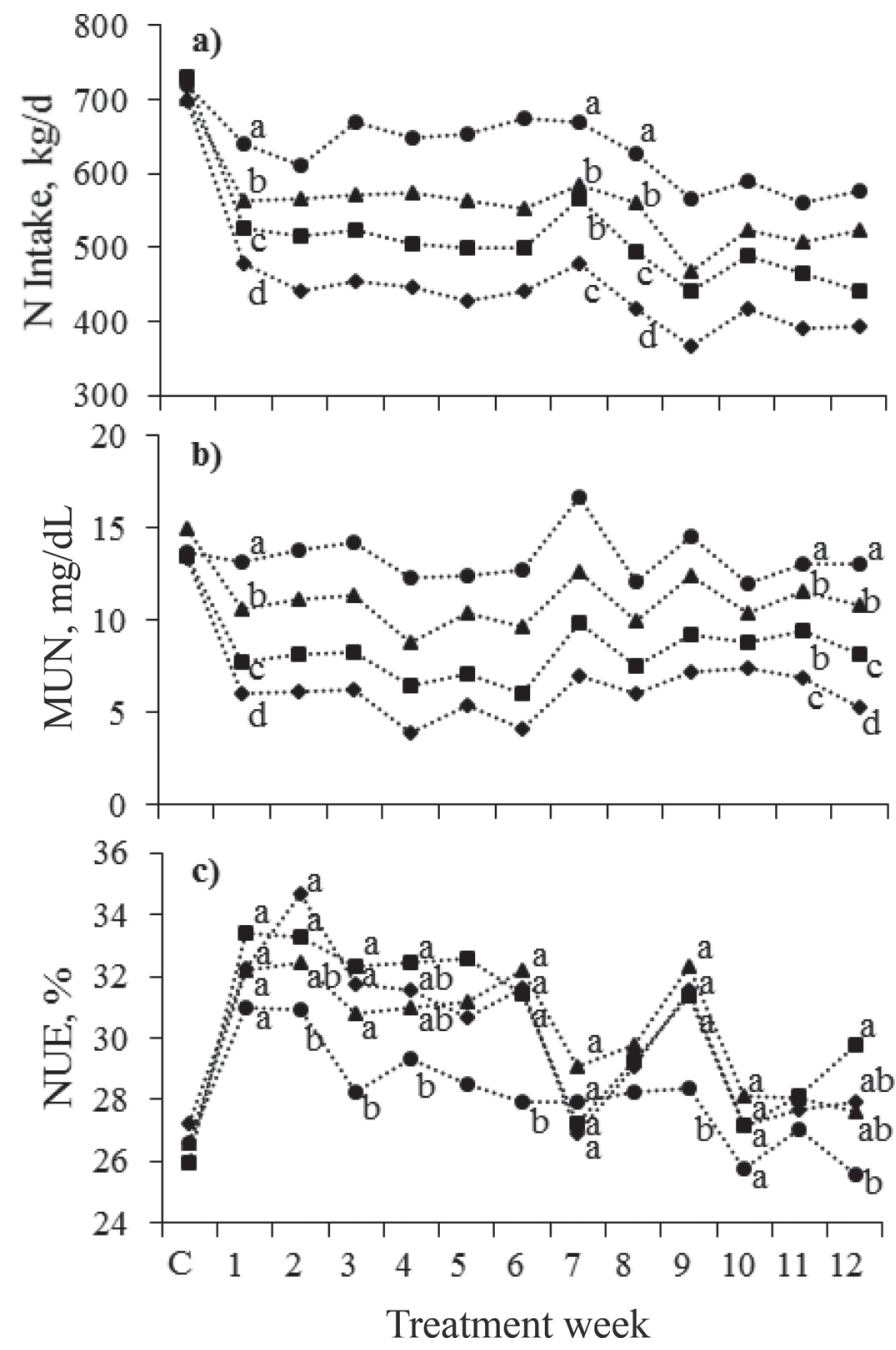

Figure 2. Covariate and covariate-adjusted least squares means for (a) weekly $\mathrm{N}$ intake (SEM $=5.9 \mathrm{~g}$ ), (b) $\mathrm{MUN}(\mathrm{SEM}=0.3 \mathrm{mg}$ / $\mathrm{dL}$ ), and (c) N use efficiency (NUE; SEM $=0.78 \%$ ) for cows in late lactation fed diets of decreasing $\mathrm{CP}$ concentration (DM basis). On the $\mathrm{x}$-axis, C depicts covariate week. Treatment diets were $16.2 \%(\bullet)$, $14.4 \%(\mathbf{\Delta}), 13.1 \%(\square)$, and $11.8 \%(\diamond) \mathrm{CP}$ (treatment $\times$ week, $P<$ 0.01 . Means within same week with different letters were different at $P \leq 0.05$. When no letters are shown, the pattern carries from the previous week.

dietary CP levels (Table 4). The NUE increased by 2.2 units when dietary CP concentration decreased by 1.8 units (from 16.2 and $14.4 \% \mathrm{CP}$ ), but there was no further increase in NUE as dietary $\mathrm{CP}$ concentration decreased from 14.4 to $13.1 \%$ and from 13.1 to $11.8 \%$. These results were unexpected because typically, when diets are in excess of dietary $\mathrm{CP}$, the reduction in $\mathrm{N}$ intake associated with a reduction in dietary $\mathrm{CP}$ concentration causes an increase in NUE (Huhtanen and Hristov, 2009). For example, Colmenero and Broderick (2006) observed that NUE increased linearly by $1.9 \pm$
0.86 percentage unit when dietary $\mathrm{CP}$ concentration was reduced from 19.4 to $13.5 \%$. Broderick (2003) also reported a linear increase in NUE from 27.0 to $30.3 \%$ when dietary CP decreased from 16.7 to $15.1 \%$. Thus, our data suggested that the typical inverse relationship between dietary CP concentration and NUE may not hold for late-lactation cows fed diets that do not meet MP requirements. The data of Law et al. (2009) suggested that the length of time necessary to adjust and reach a new steady state (i.e., constant differences among treatment) varied depending on the magnitude of change in dietary CP concentration. Recently, Zanton (2016) compared the effect of study design on the analysis of production responses when changing dietary $\mathrm{CP}$ concentration and found an interaction between dietary $\mathrm{CP}$ concentration and study design for MY and feed efficiency (but not NUE and other performance variables). However, had we used a Latin square with 3 wk of adaptations (measurements on wk 4 ), we would have reported responses more consistent with the current literature (see treatment differences for wk 4 in Figure 2c). Thus, the design of future trials to capture long-term adaptation mechanisms to low-CP diets should account for possible differential adaptation periods depending on the response variable of interest.

\section{Correlations Between Animal Performance and Indicators of N Utilization}

Table 5 presents Pearson correlations between performance data and measures of efficiency. High correlations were observed among a group of variables, including DMI, N intake, FPCM, and MPY. In contrast, milk protein percentage was correlated only with $\mathrm{N}$ intake (Table 5) and tended to be correlated with energy intake (Mcal of $\mathrm{NE}_{\mathrm{L}} / \mathrm{d} ; \mathrm{r}=0.47, P=0.07$ ). In this study, NUE did not correlate with any production and efficiency variables (Table 5), including MUN, which has been proposed as an on-farm N-management tool (Jonker et al., 2002; Wattiaux and Karg, 2004; Powell et al., 2011). It is well known that urea in the milk equilibrates rapidly with other body fluids, including plasma (Gustafsson and Palmquist, 1993), reflecting not only protein metabolism but also inefficiency of $\mathrm{N}$ utilization (Nousiainen et al., 2004). Contrary to a strong inverse relationship between NUE and MUN with increasing dietary $\mathrm{CP}$ observed in previous studies (Nousiainen et al., 2004), NUE and MUN were not negatively correlated with each other in this trial (Table 5). It might be possible that in late lactation NUE and MUN diverge from one another because they capture different aspects of $\mathrm{N}$ utilization. Compared with MUN, MUNY exhibited greater correlations with DMI, N intake, 
LATE-LACTATION PERFORMANCE AND N UTILIZATION

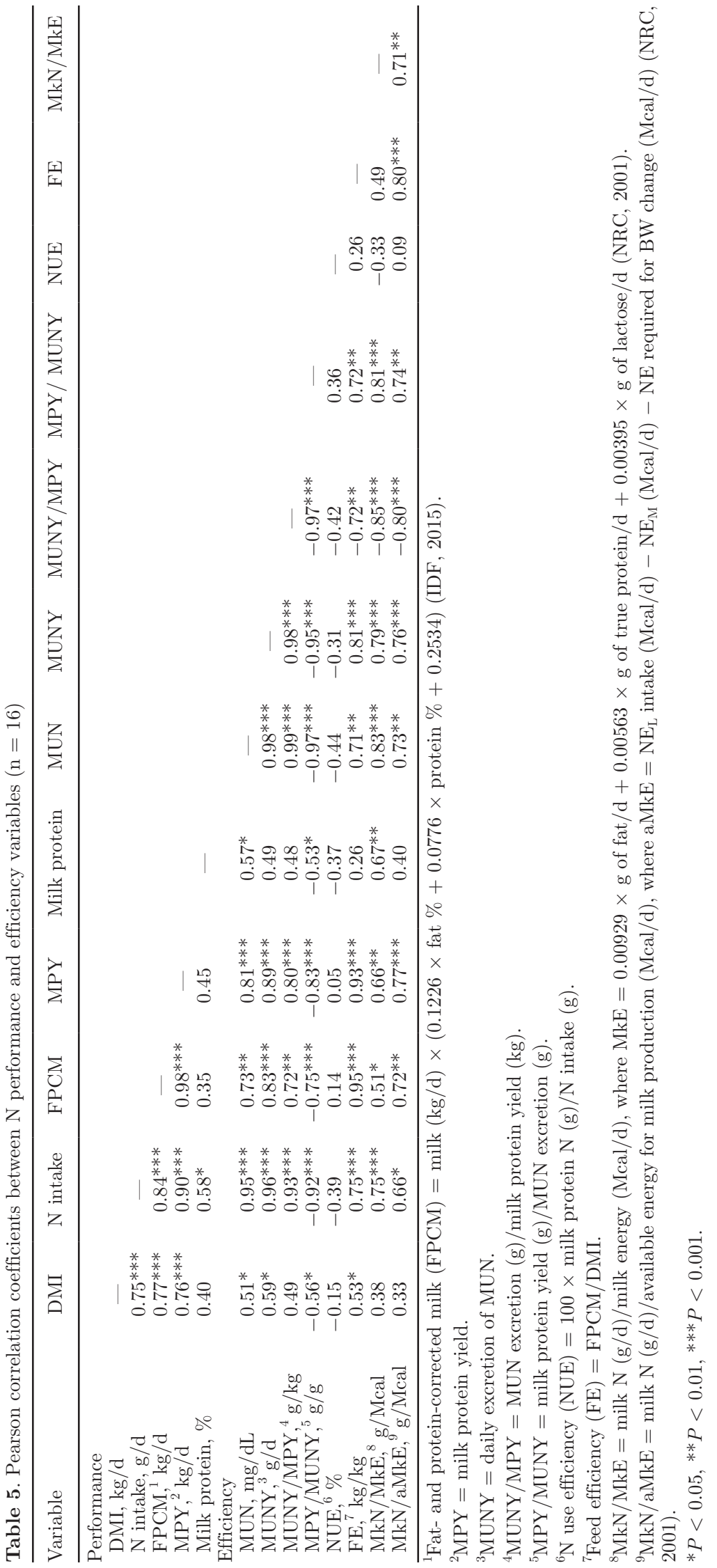


Table 6. Quadratic model with a plateau to predict maxima $\left(Y_{\max }\right)$ or minima $\left(Y_{\min }\right)$ and dietary $\mathrm{CP}$ concentration at which the response starts to decline or increase $\left(X_{o}\right)^{1,2}$

\begin{tabular}{lccccc}
\hline Item $^{3}$ & $Y_{\max }$ or $Y_{\min }{ }^{4}$ & $b$ & $X_{o}^{5}$ & $P$-value & MSE $^{7}$ \\
\hline Milk yield, kg/d & $31.9(0.20)$ & $0.46(0.067)$ & $15.54(0.28)$ & 0.04 & 0.0417 \\
FPCM, kg/d & $32.6(0.17)$ & $0.48(0.060)$ & $15.45(0.24)$ & 0.03 & 0.0298 \\
ECM, kg/d & $35.7(0.10)$ & $0.52(0.036)$ & $15.47(0.13)$ & 0.02 & 0.0112 \\
True protein yield, kg/d & $1.12(0.013)$ & $0.015(0.003)$ & $16.23(0.44)$ & 0.06 & 0.0557 \\
Fat yield, kg/d & $1.31(0.014)$ & $0.017(0.006)$ & $15.31(0.61)$ & 0.09 & 0.0002 \\
Lactose yield, kg/d & $1.49(0.016)$ & $0.020(0.004)$ & $15.89(0.46)$ & 0.06 & 0.0003 \\
SNF yield, kg/d & $2.91(0.010)$ & $0.039(0.002)$ & $15.98(0.03)$ & 0.02 & 0.0001 \\
Milk yield/DMI, kg/kg & $1.32(0.013)$ & $0.015(0.004)$ & $15.63(0.56)$ & 0.08 & 0.0002 \\
FPCM/DMI, kg/kg & $1.35(0.015)$ & $0.013(0.005)$ & $15.74(0.70)$ & 0.10 & 0.0002 \\
ECM/DMI, kg/kg & $1.48(0.020)$ & $0.016(0.007)$ & $15.50(0.82)$ & 0.12 & 0.0041 \\
MPY/MUNY, g/g & $276(18.0)$ & $19.29(4.35)$ & $16.11(0.50)$ & 0.07 & 333 \\
\hline
\end{tabular}

${ }^{1}$ Quadratic model with a plateau: If $X \leq X_{o}$ then $Y=Y_{\max }-b\left(X_{o}-X\right)^{2}$, else $Y=Y_{\max }$, where $Y$ is the response variable, $Y_{\max }$ is the plateau, $X$ is dietary CP concentration, $X_{o}$ is the dietary CP concentration at which the response starts to decline from $Y_{\max }$ as dietary CP concentration is reduced, and $b$ is a parameter that describes the curvature of the saturation curve. For item MPY/MUNY, the model was If $X \geq X_{o}$ then $Y=Y_{\min }+b\left(X_{o}-X\right)^{2}$, or else $Y=Y_{\min }$, where $X$ and $b$ are as previously defined and $X_{o}$ is the dietary CP concentration at which MPY/MUNY no longer declines $\left(Y_{\min }\right)$ as dietary CP concentration is reduced.

${ }^{2}$ Values in parentheses indicate standard error.

${ }^{3}$ Fat- and protein-corrected milk $(\mathrm{FPCM})=$ milk yield $(\mathrm{kg} / \mathrm{d}) \times(0.1226 \times$ fat $\%+0.0776 \times$ true protein $\%+$ $0.2534)(\mathrm{IDF}, 2015) . \mathrm{ECM}=(12.95 \times$ fat yield $)+(7.65 \times$ true protein yield $)+(0.327 \times$ milk yield $)(\mathrm{DRMS}$, 2014). MPY /MUNY $(\mathrm{g} / \mathrm{g})=$ milk protein yield $(\mathrm{g}) / \mathrm{MUN}$ yield $(\mathrm{g})$.

${ }^{4} Y_{\max }=$ predicted maxima; $Y_{\min }=$ predicted minima for item MPY/MUNY.

${ }^{5} X_{o}=$ predicted dietary CP concentration at which $Y_{\max }$ starts to decrease or $Y_{\min }$ starts to increase.

${ }^{6}$ Model $P$-value.

${ }^{7}$ Mean square error.

FPCM, MPY, and feed efficiency. Moreover, according to Nousiainen et al. (2004), MUNY (referred to as MUN secretion, or MUNS, in their paper) improved the prediction of urinary $\mathrm{N}$ excretion and NUE relative to MUN. Calculating the MPY/MUNY ratio by dividing MPY (g/d, reflecting the desirable use of $\mathrm{N})$ by MUNY $(\mathrm{g} / \mathrm{d}$, reflecting the inefficiency of $\mathrm{N}$ utilization) may provide a useful indicator for evaluating NUE on dairy farms (Fadul-Pacheco et al., 2017). The potential use of this ratio may also be justified by its high negative correlations with N intake, MPY, MUN, and MUNY (Table 5). In this study the lowest (and presumably most desirable) value for the MPY/MUNY ratio was $276 \mathrm{~g} / \mathrm{g}$ (Table 6). However, more studies should be done with a wider range of dietary CP (or MP) to determine the value that captures the dietary situations that maximize protein yield while minimizing urinary urea $\mathrm{N}$.

\section{Dietary CP at Which Response Variables Started to Decline}

Table 6 and Figure 3 show the results of the quadratic model with a plateau used to predict the dietary $\mathrm{CP}$ concentration at which the variables that exhibited a quadratic response started to decline (or increase, in the case of MPY/MUNY) with a reduction in di- etary CP concentration. For MY, FPCM, and ECM the predicted maximum $\left(Y_{\max }\right)$ was $31.9,32.6$, and $35.7 \mathrm{~kg} / \mathrm{d}$, respectively, and each of these values was predicted to start declining when $\mathrm{CP}$ concentration was below $15.5 \%$ of diet DM ( $X_{o}$ in Table 6 ). Dividing MY, FPCM, and ECM by DMI resulted in feed efficiency values with $Y_{\max }$ of $1.32,1.35$, and $1.48 \mathrm{~kg} /$ $\mathrm{kg}$, which were predicted to start declining as $\mathrm{CP}$ in dietary DM was reduced below 15.6, 15.7, and 15.9\%, respectively. The predicted dietary $\mathrm{CP}$ at which milk component yields started to decline from their maxima varied substantially among milk components and was $15.3,15.9,16.2$, and $16.0 \%$ for fat $(1.31 \mathrm{~kg} / \mathrm{d})$, lactose $(1.49 \mathrm{~kg} / \mathrm{d}), \operatorname{MPY}(1.12 \mathrm{~kg} / \mathrm{d})$, and SNF $(2.91 \mathrm{~kg} / \mathrm{d})$, respectively. Figure $3 \mathrm{c}$ depicts the greater resilience of fat yield compared with lactose yield and protein yield to a reduction in dietary $\mathrm{CP}$ concentration. Compared with these results, decreasing dietary $\mathrm{CP}$ concentration in 4 steps between 19.4 and $13.5 \%$ with cows averaging $120 \pm 76$ DIM had no effect on lactose yield, a (negative) linear effect on fat yield, and a tendency for a quadratic effect on MPY yield (Colmenero and Broderick, 2006). The curvilinear response for the MPY/MUNY ratio suggested an increase in MPY per unit of MUNY once $\mathrm{CP}$ concentration was reduced below $16.1 \%$ of dietary DM (Table 7). Our data (not shown) agreed with Nousiainen et al. (2004), suggesting that MUNY 

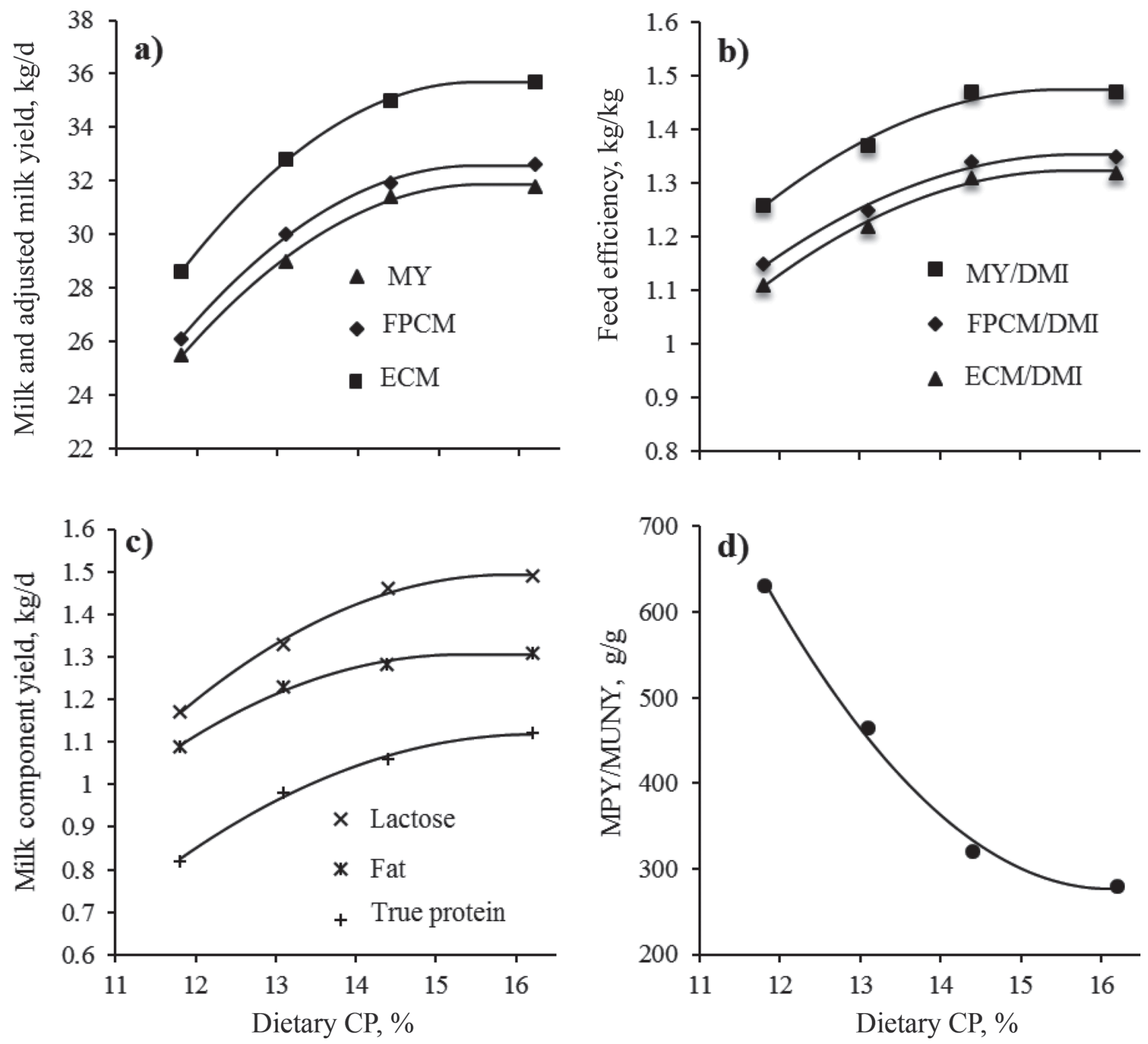

Figure 3. Quadratic model with plateau (lines) and covariate-adjusted least squares means (data points) of variables that showed a quadratic response to reduced dietary $\mathrm{CP}$ concentration. (a) Milk yield $(\mathrm{kg} / \mathrm{d})$. MY = milk yield; FPCM = fat- and protein-corrected milk. (b) Feed efficiency $(\mathrm{kg} / \mathrm{kg})$ measured as MY/DMI, FPCM/DMI, and ECM/DMI. (c) Yield (kg/d) of lactose, fat, and true protein. (d) Milk true protein yield/MUN yield (MPY/MUNY; g/g).

has the same or better predictive power of daily urinary urea N excretion compared with MUN (Kauffman and St-Pierre, 2001). Thus, our findings that the $Y_{\max }$ for MPY was almost identical to the $Y_{\min }$ for MPY/MUNY suggested that there was no opportunity to decrease urea losses without penalizing MPY under the conditions of this trial. However, an MPY/MUNY ratio less than 276 may reflect feeding situations with excess dietary $\mathrm{CP}$ or poor utilization of dietary $\mathrm{CP}$ leading to avoidable losses of urea.

\section{NRC (2001) Predictions}

Using the observed performance data of cows in this trial, NRC-predicted energy balance was positive, but predicted MP balance was negative for all 
Table 7. NRC (2001) model predictions ${ }^{1}$ and observed cow performance for cows in this study

\begin{tabular}{|c|c|c|c|c|}
\hline \multirow[b]{2}{*}{ Item } & \multicolumn{4}{|c|}{ Dietary CP, $\%$ of DM } \\
\hline & 16.2 & 14.4 & 13.1 & 11.8 \\
\hline \multicolumn{5}{|l|}{$\mathrm{NE}_{\mathrm{L}}, \mathrm{Mcal} / \mathrm{d}$} \\
\hline Supplied & 38.1 & 37.3 & 36.7 & 34.7 \\
\hline Required & 36.7 & 35.8 & 34.8 & 31.3 \\
\hline Balance & 1.4 & 1.6 & 1.9 & 3.3 \\
\hline RDP, \% of DM & 11.1 & 10.2 & 9.2 & 8.4 \\
\hline RUP, \% of DM & 5.2 & 4.6 & 4.0 & 3.4 \\
\hline \multicolumn{5}{|l|}{ Balance, g/d } \\
\hline $\mathrm{MP}$ & -109 & -187 & -336 & -398 \\
\hline RDP & 277 & 64 & -144 & -336 \\
\hline RUP & -133 & -234 & -438 & -547 \\
\hline \multicolumn{5}{|l|}{ Milk yield, $\mathrm{kg} / \mathrm{d}$} \\
\hline $\mathrm{NE}_{\mathrm{L}}$ allowable milk ${ }^{2}$ & 33.5 & 33.4 & 31.4 & 29.8 \\
\hline MP allowable milk $^{3}$ & 29.8 & 27.8 & 22.6 & 17.5 \\
\hline Observed - predicted $^{4}$ & 2.0 & 3.6 & 6.4 & 8.0 \\
\hline \multicolumn{5}{|l|}{ DMI, kg/d } \\
\hline Predicted & 26.0 & 25.5 & 25.1 & 23.3 \\
\hline Observed - predicted $^{5}$ & 1.8 & 1.7 & 1.3 & 0.6 \\
\hline \multicolumn{5}{|c|}{$\begin{array}{l}{ }^{1} \text { Prediction based on the NRC (2001) model and the treatment means of DMI, milk yield, milk composition, } \\
\text { and BW as well as measured ingredient composition. }\end{array}$} \\
\hline \multicolumn{5}{|c|}{${ }^{2} \mathrm{NRC}$ (2001)-predicted milk production based on supply of $\mathrm{NE}_{\mathrm{L}}$} \\
\hline \multicolumn{5}{|c|}{${ }^{3} \mathrm{NRC}$ (2001)-predicted milk yield based on supply of MP. } \\
\hline \multicolumn{5}{|c|}{$\begin{array}{l}{ }^{4} \text { Difference between observed milk yield and NRC (2001)-predicted MP allowable milk. } \\
{ }^{5} \text { Difference between observed DMI and NRC (2001)-predicted DMI based on treatment means of milk }\end{array}$} \\
\hline \multicolumn{5}{|c|}{$\begin{array}{l}{ }^{5} \text { Difference between observed DMI and NRC (2001)-predicted DMI based on treatment means of milk yield } \\
\text { and milk composition. }\end{array}$} \\
\hline
\end{tabular}

diets (Table 7). In addition, NRC-predicted RDP and RUP (\% of DM) decreased with decreasing dietary CP concentration. Predicted RDP was less than $10 \%$ of DM for treatments with 13.1 and $11.8 \% \mathrm{CP}$; however, this was of minor concern because Cyriac et al. (2008) reported that mid-lactation dairy cows fed RDP diets of $8.8 \%(15.9 \% \mathrm{CP})$ of DM maintained DMI, MY, and MPY compared with cows fed high-RDP diets, suggesting that ruminal microbial RDP requirements may be met with levels of RDP below those recommended by NRC (2001). Moreover, a meta-analysis (Huhtanen and Hristov, 2009) suggested that the NRC (2001) model overestimates MP requirements. In this study, predicted MP, RDP, and RUP balances (g/d) decreased with decreasing dietary $\mathrm{CP}$ concentration (Table 7). However, cows produced 2.6, 3.6, 6.4, and $8.0 \mathrm{~kg} / \mathrm{d}$ more milk compared with NRC-predicted MP allowable milk for dietary $\mathrm{CP}$ concentrations of 16.2, $14.4,13.1$, and $11.8 \%$, respectively. Model bias can be attributed in part to the fact that the NRC (2001) equations were built with a database of studies that included primarily cows in early to mid lactation fed on average $17.1 \pm 2.6 \% \mathrm{CP}$ diets. However, late-lactation cows in this study performed somewhat similarly to the corrected MP allowable milk as proposed by Lee et al. (2012), with adjustment calculated (based on the MP balance presented in Table 7) to be 2.4, 4.2, 7.6, and
$9.1 \mathrm{~kg} / \mathrm{d}$ for the diets with $16.2,14.4,13.1$, and $11.8 \%$ $\mathrm{CP}$, respectively.

\section{CONCLUSIONS}

Under the conditions of this study, decreasing dietary CP concentration decreased DMI, MUN, and MUNY linearly. Linear and quadratic responses were detected for MY, FPCM, and ECM and for the yields of fat, true protein, and lactose. Although most response variables responded within a few weeks when the decrease in dietary CP was severe (from 16.2 to 13.1 or $11.8 \%$ of $\mathrm{DM})$, the subtler decrease in CP from 16.2 to 14.4 led to a long-term readjustment in milk protein content. These findings may have implications for the design of future trials aiming at studying mechanisms of adaptation of late-lactation cows to low-CP diets. In this study, NUE averaged $30 \%$. The absence of a consistent increase in NUE with lower CP concentration and the absence of correlation between NUE and any other variables related to $\mathrm{N}$ utilization were inconsistent with the previous literature but may be related to the fact that diets were deficient in MP or may indicate an apparent limit of NUE of late-lactation cows. However, MUN, MUNY, and the MPY/MUNY ratio were highly correlated with dietary CP, N intake, MPY, FPCM, and feed efficiency. Future research should focus on im- 
proving the MP supply in low-CP diets and evaluating the reliability of MUNY and MPY/MUNY as indicators of $\mathrm{N}$ utilization in lactating dairy cows.

\section{ACKNOWLEDGMENTS}

Partial funding for the study was provided by USDA Hatch formula fund no. WIS01725 and WIS01660 (USDA, Washington, DC). The authors thank the students involved in this project (Bethany Dado, Shayna Welch, and Vítor Bettero, among other graduate students) for their valuable assistance. Appreciation is also extended to Sandy Trower and staff at the University of Wisconsin-Madison Blaine Dairy Cattle Center (Arlington, WI) for their excellent animal care, and to the reviewers for their suggestions to improve the quality of this publication.

\section{REFERENCES}

Allen, M. S. 2000. Effects of diet on short-term regulation of feed intake by lactating dairy cattle. J. Dairy Sci. 83:1598-1624. https:// doi.org/10.3168/jds.S0022-0302(00)75030-2.

AOAC. 1990. Official Methods of Analysis. 15th ed. AOAC, Gaithersburg, MD.

AOAC International. 2000. Official Methods of Analysis. 17th ed. AOAC International, Gaithersburg, MD.

AOAC International. 2006. Official Methods of Analysis. 18th ed. AOAC International, Gaithersburg, MD.

Bach Knudsen, K. E. 1997. Carbohydrate and lignin contents of plant materials used in animal feeding. Anim. Feed Sci. Technol. 67:319 338. https://doi.org/10.1016/S0377-8401(97)00009-6.

Bequette, B. J., M. D. Hanigan, H. Lapierre, and J. P. F. D'Mello. 2003. Mammary uptake and metabolism of amino acids by lactating ruminants. Pages 347-365 in Amino Acids in Animal Nutrition. 2nd ed. J. P. F. D'Mello, ed. CABI Publishing, Wallingford, UK. https://doi.org/10.1079/9780851996547.0000.

Broderick, G. A. 2003. Effects of varying dietary protein and energy levels on the production of lactating dairy cows. J. Dairy Sci. 86:1370-1381. https://doi.org/10.3168/jds.S0022-0302(03)737217.

Burgos, S. A., J. G. Fadel, and E. J. DePeters. 2007. Prediction of ammonia emission from dairy cattle manure based on milk urea nitrogen: Relation of milk urea nitrogen to urine urea nitrogen excretion. J. Dairy Sci. 90:5499-5508. https://doi.org/10.3168/ jds.2007-0299.

Cabrita, A. R. J., R. J. Dewhurst, D. S. P. Melo, J. M. Moorby, and A. J. M. Fonseca. 2011. Effects of dietary protein concentration and balance of absorbable amino acids on productive responses of dairy cows fed corn silage-based diets. J. Dairy Sci. 94:4647-4656. https://doi.org/10.3168/jds.2010-4097.

Colmenero, J. J. O., and G. A. Broderick. 2006. Effect of dietary crude protein concentration on milk production and nitrogen utilization in lactating dairy cows. J. Dairy Sci. 89:1704-1712. https://doi. org/10.3168/jds.S0022-0302(06)72238-X.

Cyriac, J., A. G. Rius, M. L. McGilliard, R. E. Pearson, B. J. Bequette, and M. D. Hanigan. 2008. Lactation performance of mid-lactation dairy cows fed ruminally degradable protein at concentrations lower than National Research Council recommendations. J. Dairy Sci. 91:4704-4713. https://doi.org/10.3168/jds.2008-1112.

Dairy Records Management Systems (DRMS). 2014. DHIA glossary. Accessed Aug. 18, 2016. http://citeseerx.ist.psu.edu/viewdoc/dow nload?doi $=10 \cdot 1 \cdot 1 \cdot 686 \cdot 2482 \&$ rep $=$ rep1\&type $=$ pdf.
Fadul-Pacheco, L., D. Pellerin, P. Y. Chouinard, M. A. Wattiaux, M. Duplessis, and E. Charbonneau. 2017. Nitrogen efficiency of commercial dairy herds: Effect on production performance and farm profitability. J. Dairy Sci. https://doi.org/10.3168/jds.2016-11788.

Ferraretto, L. F., R. D. Shaver, and S. J. Bertics. 2012. Effect of dietary supplementation with live-cell yeast at two dosages on lactation performance, ruminal fermentation, and total-tract nutrient digestibility in dairy cows. J. Dairy Sci. 95:4017-4028. https://doi. org/10.3168/jds.2011-5190.

Fredin, S. M., M. S. Akins, L. F. Ferraretto, and R. D. Shaver. 2015. Effects of corn-based diet starch content and neutral detergent fiber source on lactation performance, digestibility, and bacterial protein flow in dairy cows. J. Dairy Sci. 98:554-565. https://doi. org/10.3168/jds.2014-8592.

Godden, S. M., K. D. Lissemore, D. F. Kelton, K. E. Leslie, J. S. Walton, and J. H. Lumsden. 2001. Relationships between milk urea concentrations and nutritional management, production, and economic variables in Ontario dairy herds. J. Dairy Sci. 84:1128-1139. https://doi.org/10.3168/jds.S0022-0302(01)74573-0.

Gustafsson, A. H., and D. L. Palmquist. 1993. Diurnal variation of rumen ammonia, serum urea, and milk urea in dairy cows at high and low yields. J. Dairy Sci. 76:475-484. https://doi.org/10.3168/ jds.S0022-0302(93)77368-3.

Holden, L. A. 1999. Comparison of methods of in vitro dry matter digestibility for ten feeds. J. Dairy Sci. 82:1791-1794. https://doi. org/10.3168/jds.S0022-0302(99)75409-3.

Hristov, A. N., R. P. Etter, J. K. Ropp, and K. L. Grandeen. 2004. Effect of dietary crude protein level and degradability on ruminal fermentation and nitrogen utilization in lactating dairy cows. J. Anim. Sci. 82:3219-3229. https://doi.org/10.2527/2004.82113219x.

Huhtanen, P., and A. N. Hristov. 2009. A meta-analysis of the effects of dietary protein concentration and degradability on milk protein yield and milk N efficiency in dairy cows. J. Dairy Sci. 92:32223232. https://doi.org/10.3168/jds.2008-1352.

International Dairy Federation (IDF). 2015. A Common Carbon Footprint Approach for Dairy: The IDF Guide to Standard Lifecycle Assessment Methodology for the Dairy Sector. Bulletin 445/2010. IDF, Brussels, Belgium.

Ipharraguerre, I. R., and J. H. Clark. 2005. Varying protein and starch in the diet of dairy cows. II. Effects on performance and nitrogen utilization for milk production. J. Dairy Sci. 88:2556-2570. https://doi.org/10.3168/jds.S0022-0302(05)72932-5.

Jonker, J. S., R. A. Kohn, and J. High. 2002. Use of milk urea nitrogen to improve dairy cow diets. J. Dairy Sci. 85:939-946. https://doi. org/10.3168/jds.S0022-0302(02)74152-0.

Kaiser, R., and R. D. Shaver. 2006. Benchmarking high producing herds. Pages 179-190 in Proc. Western Canadian Dairy Semin., Red Deer, Alberta, Canada. University of Alberta, Edmonton, AB, Canada.

Kauffman, A. J., and N. R. St-Pierre. 2001. The relationship of milk urea nitrogen to urine nitrogen excretion in Holstein and Jersey cows. J. Dairy Sci. 84:2284-2294. https://doi.org/10.3168/jds. S0022-0302(01) 74675-9.

Law, R. A., F. J. Young, D. C. Patterson, D. J. Kilpatrick, A. R. G. Wylie, and C. S. Mayne. 2009. Effect of dietary protein content on animal production and blood metabolites of dairy cows during lactation. J. Dairy Sci. 92:1001-1012. https://doi.org/10.3168/ jds.2008-1155.

Lee, C., A. N. Hristov, K. S. Heyler, T. W. Cassidy, H. Lapierre, G. A. Varga, and C. Parys. 2012. Effects of metabolizable protein supply and amino acid supplementation on nitrogen utilization, milk production, and ammonia emissions from manure in dairy cows. J. Dairy Sci. 95:5253-5268. https://doi.org/10.3168/jds.2012-5366.

National Research Council (NRC). 2001. Nutrient Requirements of Dairy Cattle. 7th rev. ed. Natl. Acad. Press, Washington, DC.

Nousiainen, J., K. J. Shingfield, and P. Huhtanen. 2004. Evaluation of milk urea nitrogen as a diagnostic of protein feeding. J. Dairy Sci. 87:386-398. https://doi.org/10.3168/jds.S0022-0302(04)73178-1.

Powell, J. M., M. A. Wattiaux, and G. A. Broderick. 2011. Short communication: Evaluation of milk urea nitrogen as a management 
tool to reduce ammonia emissions from dairy farms. J. Dairy Sci. 94:4690-4694. https://doi.org/10.3168/jds.2011-4476.

Reynolds, C. K., and N. B. Kristensen. 2008. Nitrogen recycling through the gut and the nitrogen economy of ruminants: An asynchronous symbiosis. J. Anim. Sci. 86(Suppl.):E293-E305. https:// doi.org/10.2527/jas.2007-0475.

SAS Institute. 2012. SAS/STAT 9.3 User's Guide. Version 9.3 ed. SAS Institute Inc., Cary, NC.

Schaalje, B. G., J. B. McBride, and G. W. Fellingham. 2001. Approximations to distributions of test statistics in complex mixed linear models using SAS Proc MIXED. Accessed Oct. 16, 2016. http:// www2.sas.com/proceedings/sugi26/p262-26.pdf.

St-Pierre, N. R. 2007. Design and analysis of pen studies in the animal sciences. J. Dairy Sci. 90(E. Suppl.):E87-E99. https://doi. org/10.3168/jds.2006-612.

St-Pierre, N. R., and D. Gerstner. 2005. Effects of daily variation in dietary protein concentration on milk production in mid-lactation cows. J. Dairy Sci. 88(Suppl. 1):91. (Abstr.)

Steinfeld, H., P. Gerber, T. Wassenaar, V. Castel, M. Rosales, and C. De Haan. 2006. Livestock's Long Shadow: Environmental Issues and Options. Food Agric. Organ., Rome, Italy.
Van Soest, P. J., J. B. Robertson, and B. A. Lewis. 1991. Methods for dietary fiber, neutral detergent fiber, and nonstarch polysaccharides in relation to animal nutrition. J. Dairy Sci. 74:3583-3597. https://doi.org/10.3168/jds.S0022-0302(91)78551-2.

Wattiaux, M. A., and K. L. Karg. 2004. Protein level for alfalfa and corn silage-based diets: II. Nitrogen balance and manure characteristics. J. Dairy Sci. 87:3492-3502. https://doi.org/10.3168/jds S0022-0302(04)73484-0.

Wildman, E. E., G. M. Jones, P. E. Wagner, R. L. Boman, H. F Troutt, and T. N. Lesch. 1982. A dairy cow body condition scoring system and its relationship to selected production characteristics. J. Dairy Sci. 65:495-501. https://doi.org/10.3168/jds.S00220302(82)82223-6.

Zanton, G. I. 2016. Analysis of production responses to changing crude protein levels in lactating dairy cow diets when evaluated in continuous or change-over experimental designs. J. Dairy Sci. 99:4398-4410. https://doi.org/10.3168/jds.2015-10438. 